\title{
Treatment Volume Determination for Irradiation Ofrecurrent Nasopharyngeal Carcinoma with Multimodality Imaging: An Original Article
}

\author{
Omer Sager $^{1}$, Ferrat Dincoglan ${ }^{1}$, Selcuk Demiral ${ }^{1}$, Murat Beyzadeoglu ${ }^{1}$ \\ ${ }^{I}$ Department of Radiation Oncology; University of Health Sciences, Gulhane Medical Faculty, Ankara, Turkey \\ *Corresponding Author: Omer Sager, Department of Radiation Oncology; University of Health \\ Sciences, Gulhane Medical Faculty, Ankara, Turkey
}

\begin{abstract}
Objective: RT planning for nasopharyngeal carcinoma is typically based on computed tomography $(C T)$ simulation of the patients in treatment position. While CT is essential for dose calculations and RT planning, additional data from multimodality imaging may assist in accurate target definition. In this original research article, we assess treatment volume determination for irradiation of recurrent nasopharyngeal carcinoma with multimodality imaging.
\end{abstract}

Materials and Methods: Determination of treatment volumeby multimodality imaging with incorporation ofmagnetic resonance imaging (MRI) or byCT-simulation images only has been assessed with comparative evaluation in patients receiving irradiation for recurrent nasopharyngeal carcinoma.

Results: Contemporary RT planning systems at our department have been utilized for precise radiation treatment planning. Adequate coverage of treatmentvolumes with optimal sparing of critical structures were prioritized in RT planning. Definition of ground truth target volume has beenaccomplished by boardcertified radiation oncologists following comprehensive evaluation, collaboration, colleague peer review and ultimate consensus to be utilized for actual treatment and for comparative analysis. Synergy (Elekta, UK) LINAC has been utilized forirradiation.Treatment volume definition by CT-only imaging and by CT-MR fusion based imaging has been evaluated with comparative assessment. As the result, ground truth target volume has been found to be identical with treatment volumedeterminationby CT-MR fusion based imaging.

Conclusion: Inclusion of MRI in RT planning proceduremay be considered for improving the therapeutic ratio through optimization of target and treatment volume definition for precise and accurate reirradiation despite the need for further supporting evidence.

Keywords: nasopharyngeal carcinoma,reirradiation, recurrence, magnetic resonance imaging (MRI)

\section{INTRODUCTION}

Nasopharyngeal carcinoma is a frequent head and neck neoplasm which is endemic in Southern China [1-3]. Patients with nasopharyngeal carcinoma may benefit from multidisciplinary management including systemic agents and radiation therapy (RT). Since the role of surgery is typically limited for nasopharyngeal carcinoma treatment, RT constitutes an integral part of multimodality management. In the context of RT, there has been substantial progress in cancer management over the years with introduction of contemporary irradiation strategies, adaptive RT approaches, automatic segmentation techniques, molecular imaging methods, stereotactic irradiation, along with modernized treatment delivery techniques such as Image Guided
Radiation Therapy (IGRT), Intensity Modulated Radiation Therapy (IMRT), Adaptive Radiation Therapy (ART), Breathing Adapted Radiation Therapy (BART) [4-41].While the improvements in radiation oncology are encouraging, the toxicity profile of radiation delivery remains to be a concern for patients receiving RT for nasopharyngeal carcinoma. In the setting of locally recurrent disease, it is more critical to consider adverse effects of reirradiation to avoid severe complications which may deteriorate quality of life and functionality.

RT planning for nasopharyngeal carcinoma is typically based on computed tomography (CT) simulation of the patients in treatment position. While CT is essential for dose calculations and RT planning, additional data from 
multimodality imaging may assist in accurate target definition. In this original research article, we assess treatment volume determination for irradiation of recurrent nasopharyngeal carcinoma with multimodality imaging.

\section{Materials And Methods}

Determination of treatmentvolumeby multimodality imaging withincorporation ofmagnetic resonance imaging (MRI) or byCTsimulation images only has been assessed with comparative evaluation in patients receiving irradiation for recurrent nasopharyngeal carcinoma. Ground truth target volume serving asthe reference for actual treatment and comparison purposes has been comprehensively determinedby the boardcertified radiation oncologists followingthoroughevaluation, collaboration, colleague peer review, and ultimate consensus. Detailed assessmenthas beenperformed individuallywith consideration of lesion size, localization, symptomatology, patient preferences, andexpectedoutcomes of irradiation. CT-simulator (GE Lightspeed RT, GE Healthcare, Chalfont St. Giles, UK)has been utilized for radiation treatment simulation for RT planning at our tertiary cancer center. Planning CT images wereacquired and transferred to the contouring workstation (SimMD, GE, UK) for outlining of treatment volumes and surroundingcritical structures. Either CT-simulation images only or fused CT and MR imageshave been consideredfor treatment volume determination for RT. Treatment volume definition with CT only and with incorporation of CT-MR fusion has been comparatively assessed. Synergy (Elekta, UK) linear accelerator (LINAC) hasbeen used for treatment delivery andIGRT techniques were routinely incorporated in radiotherapeutic management.

\section{ReSUlts}

Contemporary RT planning systems at our department havebeen utilized for precise radiation treatment planning. Adequate coverage of treatmentvolumes with optimal sparing of critical structureswere prioritized in RT planning. Definition of ground truth target volume has beenaccomplished by boardcertified radiation oncologists following comprehensive evaluation, collaboration, colleague peer review and ultimate consensus to be utilized for actual treatment and for comparative analysis. Synergy (Elekta, UK) LINAC has been utilized forirradiation.Treatment volume definition by
CT-only imaging and by CT-MR fusion based imaging has been evaluated with comparative assessment. As the result, ground truth target volume has been found to be identical with treatment volumedeterminationby CT-MR fusion based imaging.

\section{Discussion}

Nasopharyngeal carcinoma constitutes an important health concern as a frequent head and neck neoplasm particularly in Southern China. Affected patients may suffer from a plethora of symptoms since this critical region of the human body and its neighborhood may be associated with several functions including digestion, swallowing, hearing, speaking, and other important functions. Surgical resection has a limited role in management of nasopharyngeal carcinoma. Thus, RT and systemic agents are primarily used as therapies. RT has a major role in treatment, and encouraging treatment outcomes may be achieved with multidisciplinary management. However, patients may suffer from recurrent disease which is typically more difficult to manage. Main challenge in management of recurrent nasopharyngeal carcinoma is due to high delivered doses in the primary disease setting, and the need for limiting the reirradiation dose for avoidance of adverse radiation effects. Excessive exposure of critical structures at reirradiation may result in substantial morbidity which may be considered as a significant burden on the patients. Nevertheless, irradiation has been utilized for management of recurrent nasopharyngeal carcinoma [42-44].

Precise target and treatment volume definition is a critical component of reirradiation for recurrent nasopharyngeal carcinoma. While the typical RT planning process includes utilization of CT-simulation, multimodality imaging may add to the precision and accuracy of target definition. In the literature, several studies have addressed the utility of multimodality imaging for improved treatment volume determination [45-67]. Contemporary techniquesincluding radiosurgical applications under rigid stereotactic immobilization and image guidance may improve radiotherapeutic management, however, target definition becomes more critical in the context of stereotactic irradiation sincehigher dose of radiation is typically delivered in a single or a few fractions. Defining larger than actual target volumes may lead to excessive critical organ exposure and resultant 
morbidity. On the other hand, determinationof smaller than actual target volumes may result in inadequate coverage of treatment volumesand subsequent failure of therapy. Within this context, optimization of target definition is a critical aspect of recurrent nasopharyngeal carcinoma management. Our study supporting the role of

multimodality imaging for target definition of recurrent nasopharyngeal carcinoma may add to the existing literature.

In conclusion, inclusion of MRI inRT planning proceduremay be considered for improving the therapeutic ratio through optimization of target and treatment volume definition for precise and accurate reirradiation despite the need for further supporting evidence.

\section{REFERENCES}

[1] Li JX, Lu TX, Huang Y, Han F (2012) Clinical characteristics of recurrent nasopharyngeal carcinoma in highincidence area.ScientificWorldJournal2012:719 754.

[2] Petersson F (2015) Nasopharyngeal carcinoma: a review.Semin Diagn Pathol 32:54-73.

[3] Wei WI, Sham JS (2005) Nasopharyngeal carcinoma.Lancet 365:2041-2054.

[4] 4.Sager O, Dincoglan F, Demiral S, Uysal B, Gamsiz H, et al. (2021) Omission of Radiation Therapy (RT) for Metaplastic Breast Cancer (MBC): A Review Article. International Journal of Research Studies in Medical and Health Sciences 6: 10-15.

[5] Sager O, Dincoglan F, Demiral S, Uysal B, Gamsiz H, et al. (2020) Adaptive radiation therapy of breast cancer by repeated imaging during irradiation.World J Radiol 12: 68-75.

[6] Sager O, Beyzadeoglu M, Dincoglan F, Demiral S, Gamsiz H, et al. (2020) Multimodality management of cavernous sinus meningiomas with less extensive surgery followed by subsequent irradiation: Implications for an improved toxicity profile. $\mathbf{J}$ Surg Surgical Res 6: 056-061.

[7] Beyzadeoglu M, Sager O, Dincoglan F, Demiral S, Uysal B, et al. (2020) Single Fraction Stereotactic Radiosurgery (SRS) versus Fractionated Stereotactic Radiotherapy (FSRT) for Vestibular Schwannoma (VS). J Surg Surgical Res 6: 062-066.

[8] Sager O, Beyzadeoglu M, Dincoglan F, Demiral S, Uysal B, et al. (2020) Obsessive compulsive disorder (ocd) as a severe mental health disorder: A concise review of management with radiosurgery for intractable disease. J Surg Surgical Res 6: 100-105.
[9] Sager O, Beyzadeoglu M, Dincoglan F, Demiral S, Uysal B, et al. (2020) A concise review of irradiation sequelae on the cardiovascular system in pulmonary malignancies. J Surg Surgical Res 6: 079-083.

[10] Sager O, Beyzadeoglu M, Demiral S, Dincoglan F, Gamsiz H, et al. (2020) Assessment of cardiac sparing in radiotherapeutic Management of mediastınal hodgkın lymphoma (hl) Durıng childhood and adolescence. J Surg Surgical Res 6: 106-109.

[11] Dincoglan F, Beyzadeoglu M, Sager O, Demiral S, Uysal B, et al. (2020) A Concise Review of Irradiation for Temporal Bone Chemodectomas (TBC). Arch Otolaryngol Rhinol 6: 016-020.

[12] Dincoglan F, Sager O, Uysal B, Demiral S, Gamsiz H, et al. (2019) Evaluation of hypofractionated stereotactic radiotherapy (HFSRT) to the resection cavity after surgical resection of brain metastases: A single center experience.Indian J Cancer 56: 202-206.

[13] Dincoglan F, Sager O, Demiral S, Gamsiz H, Uysal B, et al. (2019) Fractionated stereotactic radiosurgery for locally recurrent brain metastases after failed stereotactic radiosurgery.Indian J Cancer 56: 151-156.

[14] Sager O, Dincoglan F, Demiral S, Uysal B, Gamsiz H, et al. (2019) Breathing adapted radiation therapy for leukemia relapse in the breast: A case report.World J Clin Oncol 10: 369-374.

[15] Sager O, Dincoglan F, Demiral S, Uysal B, Gamsiz H, et al. (2019) Utility of Molecular Imaging with 2-Deoxy-2-[Fluorine-18] FluoroDGlucose Positron Emission Tomography (18F-FDG PET) for Small Cell Lung Cancer (SCLC): A Radiation Oncology Perspective.Curr Radiopharm 12: 4-10.

[16] Sager O, Dincoglan F, Uysal B, Demiral S, Gamsiz H, et al. (2018) Evaluation of adaptive radiotherapy (ART) by use of replanning the tumor bed boost with repeated computed tomography (CT) simulation after whole breast irradiation (WBI) for breast cancer patients having clinically evident seroma.Jpn J Radiol 36: 401-406.

[17] Demiral S, Dincoglan F, Sager O, Uysal B, Gamsiz H, et al. (2018) Contemporary Management of Meningiomas with Radiosurgery. Int J Radiol Imaging Technol 80: 187-190.

[18] Sager O, Dincoglan F, Uysal B, Demiral S, Gamsiz H, et al. (2017) Splenic Irradiation: A Concise Review of the Literature. J App Hem B1 Tran 1: 101.

[19] Dincoglan F, Sager O, Demiral S, Uysal B, Gamsiz H, et al. (2017) Radiosurgery for 
recurrent glioblastoma: A review article. Neurol Disord Therap 1: 1-5.

[20] Demiral S, Dincoglan F, Sager O, Gamsiz H, Uysal B, et al. (2016) Hypofractionated stereotactic radiotherapy (HFSRT) for who grade I anterior clinoid meningiomas (ACM). Jpn J Radiol 34: 730-737.

[21] Gamsiz H, Beyzadeoglu M, Sager O, Demiral S, Dincoglan F, et al. (2015) Evaluation of stereotactic body radiation therapy in the management of adrenal metastases from nonsmall cell lung cancer. Tumori 101: 98-103.

[22] Sager O, Dincoglan F, Beyzadeoglu M (2015) Stereotactic radiosurgery of glomus jugulare tumors: Current concepts, recent advances and future perspectives. CNS Oncol 4: 105-114.

[23] Dincoglan F, Beyzadeoglu M, Sager O, Demiral S, Gamsiz H, et al. (2015) Management of patients with recurrent glioblastoma using hypofractionated stereotactic radiotherapy. Tumori 101: 179-184.

[24] Sager O, Beyzadeoglu M, Dincoglan F, Demiral S, Uysal B, et al. (2015) Adaptive splenic radiotherapy for symptomatic splenomegaly management in myeloproliferative disorders. Tumori 101: 8490.

[25] Ozsavaş EE, Telatar Z, Dirican B, Sager O, Beyzadeoğlu M (2014) Automatic segmentation of anatomical structures from CT scans of thorax for RTP.Comput Math Methods Med 2014: 472890.

[26] Demiral S, Beyzadeoglu M, Sager O, Dincoglan F, Gamsiz H, et al. (2014) Evaluation of Linear Accelerator (Linac)-Based Stereotactic Radiosurgery (Srs) for the Treatment of Craniopharyngiomas. UHODUluslararasi Hematoloji Onkoloji Dergisi 24(2): 123-129.

[27] Gamsiz H, Beyzadeoglu M, Sager O, Dincoglan F, Demiral S, et al. (2014) Management of pulmonary oligometastases by stereotactic body radiotherapy. Tumori 100: 179-183.

[28] Demiral S, Beyzadeoglu M, Sager O, Dincoglan F, Gamsiz H, et al. (2014) Evaluation of linear accelerator (linac)-based stereotactic radiosurgery (srs) for the treatment of craniopharyngiomas. UHOD - Uluslararasi Hematoloji-Onkoloji Dergisi 24: 123-129.

[29] Dincoglan F, Sager O, Gamsiz H, Uysal B, Demiral S, et al. (2014) Management of patients with $\geq 4$ brain metastases using stereotactic radiosurgery boost after whole brain irradiation. Tumori 100: 302-306.

[30] Sager O, Beyzadeoglu M, Dincoglan F, Gamsiz H, Demiral S, et al. (2014) Evaluation of linear accelerator-based stereotactic radiosurgery in the management of glomus jugulare tumors. Tumori 100: 184-188.

[31] Sager O, Beyzadeoglu M, Dincoglan F, Uysal B, Gamsiz H, et al. (2014) Evaluation of linear accelerator (LINAC)-based stereotactic radiosurgery (SRS) for cerebral cavernous malformations: A 15-year single-center experience. Ann Saudi Med 34: 54-58.

[32] Dincoglan F, Beyzadeoglu M, Sager O, Oysul K, Kahya YE, et al. (2013) Dosimetric evaluation of critical organs at risk in mastectomized left-sided breast cancer radiotherapy using breath-hold technique. Tumori 99: 76-82.

[33] Sager O, Beyzadeoglu M, Dincoglan F, Demiral S, Uysal B, et al. (2013) Management of vestibular schwannomas with linear accelerator-based stereotactic radiosurgery: a single center experience. Tumori 99: 617-622.

[34] Dincoglan F, Beyzadeoglu M, Sager O, Uysal B, Demiral S, et al. (2013) Evaluation of linear accelerator-based stereotactic radiosurgery in the management of meningiomas: A single center experience. J BUON 18: 717-722.

[35] Demiral S, Beyzadeoglu M, Uysal B, Oysul K, Kahya YE, et al. (2013) Evaluation of stereotactic body radiotherapy (SBRT) boost in the management of endometrial cancer. Neoplasma 60: 322-327.

[36] Sager O, Beyzadeoglu M, Dincoglan F, Oysul K, Kahya YE, et al. (2012) Evaluation of active breathing control-moderate deep inspiration breath-hold in definitive non-small cell lung cancer radiotherapy.Neoplasma 59: 333-340.

[37] Sağer Ö, Dinçoğlan F, Gamsiz H, Demiral S, Uysal B, et al. (2012) Evaluation of the impact of integrated [18f]-fluoro-2-deoxy-D-glucose positron emission tomography/computed tomography imaging on staging and radiotherapy treatment volume definition of nonsmall cell lung cancer. Gulhane Med J54: 220-227.

[38] Sager O, Beyzadeoglu M, Dincoglan F, Oysul K, Kahya YE, et al. (2012) The Role of Active Breathing Control-Moderate Deep Inspiration Breath-Hold (ABC-mDIBH) Usage in nonMastectomized Left-sided Breast Cancer Radiotherapy: A Dosimetric EvaluationUHOD - Uluslararasi Hematoloji-Onkoloji Dergisi 22: 147-155.

[39] Dincoglan F, Beyzadeoglu M, Sager O, Oysul K, Sirin S et al. (2012) Image-guided positioning in intracranial non-invasive stereotactic radiosurgery for the treatment of brain metastasis. Tumori 98: 630-635.

[40] Dincoglan F, Sager O, Gamsiz H, Uysal B, Demiral S, et al. (2012) Stereotactic 
Treatment Volume Determination for Irradiation Ofrecurrent Nasopharyngeal Carcinoma with Multimodality Imaging: An Original Article

radiosurgery for intracranial tumors: A single center experience. Gulhane Med J 54: 190-198.

[41] Sirin S, Oysul K, Surenkok S, Sager O, Dincoglan F, et al. (2011) Linear acceleratorbased stereotactic radiosurgery in recurrent glioblastoma: A single center experience. Vojnosanit Pregl 68: 961-966.

[42] Kong L, Lu JJ (2016) Reirradiation of locally recurrent nasopharyngeal cancer: history, advances, and promises for the future.Chin Clin Oncol 5:26.

[43] Kong F, Zhou J, Du C, He X, Kong L, et al. (2018) Long-term survival and late complications of intensitymodulated radiotherapy for recurrent nasopharyngeal carcinoma.BMC Cancer 18:1139.

[44] Lee AWM, Ng WT, Chan JYW, Corry J, Mäkitie A, et al. (2019) Management of locally recurrent nasopharyngeal carcinoma.Cancer Treat Rev79:101890.

[45] Demiral S, Sager O, Dincoglan F, Uysal B, Gamsiz H, et al. (2018) Evaluation of Target Volume Determination for Single Session Stereotactic Radiosurgery (SRS) of Brain Metastases. Canc Therapy \& Oncol Int J 12: 555848 .

[46] Sager O, Dincoglan F, Demiral S, Gamsiz H, Uysal B, et al. (2019) Utility of Magnetic Resonance Imaging (Imaging) in Target Volume Definition for Radiosurgery of Acoustic Neuromas. Int J Cancer Clin Res 6: 119.

[47] Sager O, Dincoglan F, Demiral S, Beyzadeoglu M (2019) Evaluation of Radiosurgery Target Volume Determination for Meningiomas Based on Computed Tomography (CT) And Magnetic Resonance Imaging (MRI). Cancer Sci Res Open Access 5: 1-4.

[48] Dincoglan F, Sager O, Demiral S, Beyzadeoglu M (2019) Multimodality Imaging for Radiosurgical Management of Arteriovenous Malformations. Asian Journal of Pharmacy, Nursing and Medical Sciences 7: 7-12.

[49] Beyzadeoglu M, Sager O, Dincoglan F, Demiral S (2019) Evaluation of Target Definition for Stereotactic Reirradiation of Recurrent Glioblastoma. Arch Can Res 7: 3.

[50] Sager O, Dincoglan F, Demiral S, Gamsiz H, Uysal B, et al. (2019) Evaluation of the Impact of Magnetic Resonance Imaging (MRI) on Gross Tumor Volume (GTV) Definition for Radiation Treatment Planning (RTP) of Inoperable High Grade Gliomas (HGGs). Concepts in Magnetic Resonance Part A 2019, Article ID 4282754.

[51] Demiral S, Sager O, Dincoglan F, Beyzadeoglu M (2019) Assessment of target definition based on Multimodality imaging for radiosurgical Management of glomus jugulare tumors (GJTs). Canc Therapy \& Oncol Int J 15: 555909 .

[52] Demiral S, Sager O, Dincoglan F, Beyzadeoglu M (2019) Assessment of Computed Tomography (CT) And Magnetic Resonance Imaging (MRI) Based Radiosurgery Treatment Planning for Pituitary Adenomas. Canc Therapy \& Oncol Int J 13: 555857.

[53] Dincoglan F, Sager O, Demiral S, Beyzadeoglu M (2019) Incorporation of Multimodality Imaging in Radiosurgery Planning for Craniopharyngiomas: An Original Article. SAJ Cancer Sci 6: 103.

[54] Sager O, Dincoglan F, Demiral S, Beyzadeoglu M (2020) Evaluation of Target Volume Determination for Irradiation of Pilocytic Astrocytomas: An Original Article. ARC Journal of Cancer Science 6: 1-5.

[55] Demiral S, Beyzadeoglu M, Dincoglan F, Sager O (2020) Evaluation of Radiosurgery Target Volume Definition for Tectal Gliomas with Incorporation of Magnetic Resonance Imaging (MRI): An Original Article. Biomedical Journal of Scientific \& Technical Research (BJSTR) 27: 20543-20547.

[56] Beyzadeoglu M, Dincoglan F, Demiral S, Sager O (2020) Target Volume Determination for Precise Radiation Therapy (RT) of Central Neurocytoma: An Original Article. International Journal of Research Studies in Medical and Health Sciences 5: 29-34.

[57] Sager O, Dincoglan F, Demiral S, Beyzadeoglu M (2020) Radiosurgery Treatment Volume Determination for Brain Lymphomas with and without Incorporation of Multimodality Imaging. Journal of Medical Pharmaceutical and Allied Sciences 9: 2398-2404.

[58] 58. Demiral S, Beyzadeoglu M, Dincoglan F, Sager O (2020) Assessment of Target Volume Definition for Radiosurgery of Atypical Meningiomas with Multimodality Imaging. Journal of Hematology and Oncology Research 3: 14-21.

[59] Beyzadeoglu M, Dincoglan F, Sager O, Demiral S (2020) Determination of Radiosurgery Treatment Volume for Intracranial Germ Cell Tumors (GCTS). Asian Journal of Pharmacy, Nursing and Medical Sciences 8: 18-23.

[60] Sager O, Demiral S, Dincoglan F, Beyzadeoglu M (2020) Target Volume Definition for Stereotactic Radiosurgery (SRS) Of Cerebral Cavernous Malformations (CCMs). Canc Therapy \& Oncol Int J 15: 555917.

[61] Dincoglan F, Demiral S, Sager O, Beyzadeoglu M (2020) Utility of Multimodality Imaging Based Target Volume Definition for 
Treatment Volume Determination for Irradiation Ofrecurrent Nasopharyngeal Carcinoma with Multimodality Imaging: An Original Article

Radiosurgery of Trigeminal Neuralgia: An Original Article. Biomed J Sci \& Tech Res 26: 19728-19732.

[62] Dincoglan F, Beyzadeoglu M, Demiral S, Sager O (2020) Assessment of Treatment Volume Definition for Irradiation of Spinal Ependymomas: an Original Article. ARC Journal of Cancer Science 6: 1-6.

[63] Sager O, Dincoglan F, Demiral S, Beyzadeoglu M (2020) Evaluation of Treatment Volume Determination for Irradiation of chordoma: an Original Article. International Journal of Research Studies in Medical and Health Sciences 5 (10): 3-8

[64] Sager O, Dincoglan F, Demiral S, Beyzadeoglu M (2020) Assessment of Target Volume Definition for Irradiation of Hemangiopericytomas: An Original Article. Canc Therapy \& Oncol Int J 17(2).

[65] Selcuk Demiral, FerratDincoglan,Omer Sager, Murat Beyzadeoglu, Multimodality Imaging
Based Target Definition of Cervical Lymph Nodes in Precise Limited Field Radiation Therapy (Lfrt) for Nodular Lymphocyte Predominant Hodgkin Lymphoma (Nlphl). ARC Journal of Cancer Science. 2020; 6(2):0611. DOI:dx.doi.org/ 10.20431/2455-6009.060 2002.

[66] Ferrat Dincoglan, Selcuk Demiral, Omer Sager, Murat Beyzadeoglu. Evaluation of Target Definition for Management of Myxoid Liposarcoma (MLS) with Neoadjuvant Radiation Therapy (RT). Biomed J Sci \& Tech Res 33(5)-2021. BJSTR. MS.ID.005458.

[67] FerratDincoglan,Omer Sager, Selcuk Demiral, Murat Beyzadeoglu, Target Definitionoforbital Embryonal Rhabdomyosarcoma (Rms) by Multimodality Imaging: An Original Article. ARC Journal of Cancer Science. 2020; 6(2):1217. DOI:dx.doi.org/ 10.20431/2455-6009.060 2003.

Citation: Omer Sager, Ferrat Dincoglan, Selcuk Demiral, Murat Beyzadeoglu. Treatment Volume Determination for Irradiation Ofrecurrent Nasopharyngeal Carcinoma with Multimodality Imaging: An Original Article. ARC Journal of Cancer Science. 2020; 6(2):18-23. DOI: dx.doi.org/10.20431/24556009.0602004.

Copyright: (C) 2020 Authors. This is an open-access article distributed under the terms of the Creative Commons Attribution License, which permits unrestricted use, distribution, and reproduction in any medium, provided the original author and source are credited. 